\title{
Peran Komunitas Kecil Bergerak Indonesia (KBI) bagi Masyarakat di Masa Pandemi COVID-19 di Sidoarjo
}

\author{
Akbar Trio Mashuri*1, Amal Taufiq² \\ ${ }^{1}$ Fakultas Dakwah dan Komunikasi, UIN Sunan Ampel Surabaya, Indonesia \\ ${ }^{2}$ FISIP, UIN Sunan Ampel Surabaya, Indonesia \\ *e-mail: akbartrio28@gmail.com ${ }^{1}{ }^{\text {amaltaufiq70@gmail.com }}{ }^{2}$
}

\begin{abstract}
Abstrak
Pertumbuhan ekonomi di Indonesia telah dinyatakan menurun akibat adanya pandemi COVID-19. Pemerintah telah menetapkan kebijakan sebagai salah satu strategi pemulihan roda ekonomi negara, salah satunya dengan memberikan bantuan bagi masyarakat terdampak, karena banyaknya penduduk di Indonesia maka untuk mencapai tujuan itu tidak bisa diserahkan pada pemerintahan saja, tapi perlu adanya partisipasi dari masyarakat dengan mengedukasi masyarakat maupun dengan bantuan riil melalui sebuah komunitas. Bertujuan untuk mengetahui dan memahami latar belakang serta kontribusinya dalam maeringankan beban ekonomi masyarakat yang terdampak pandemi COVID-19 di wilayah Sidoarjo Jawa Timur. Penelitian ini merupakan penulisan kualitatif teknik pengumpulan data dengan observasi, wawqanccara dan dokumentasi. Hasil kegiatan ini menunjukkan bahwa kontribusi komunitas Kecil Bergerak Indonesia (KBI) sebagai mitra pemerintah berpengaruh positif dalam upaya membantu masyarakat dalam memulihkan perekonomian pada masa pandemi.
\end{abstract}

Kata kunci: Bantuan COVID-19, Kecil Bergerak Indonesia (KBI), Pemulihan Ekonomi

\section{Abstract}

Economic growth in Indonesia has been declared declining due to the COVID-19 pandemic. The government has established policy as one of the country's economic recovery strategies, one of which is by providing assistance to affected communities, because the large population in Indonesia so that to achieve that goal cannot be left to the government alone, but there needs to be participation from the community by educating the community and with real assistance through a community. It aims to know and understand its background and contribution in the economic burden of people affected by the COVID-19 pandemic in the Sidoarjo region of East Java. This research is a qualitative writing of data collection techniques with observation, wawqanccara and documentation. The results of this activity show that the contribution of the Small Mobile Indonesia community (KBI) as a government partner is positively influential in efforts to help the community in restoring the economy during the pandemic.

Keywords: Economic Recovery, Help of COVID-19, Kecil Bergerak Indonesia (KBI)

\section{PENDAHULUAN}

Sejak kasus pertama di Wuhan di tahun 2019, terjadi peningkatan kasus COVID-19 setiap harinya. COVID-19 merupakan penyakit menular yang disebabkan virus bernama SARSCOV-1 atau sering disebut dengan virus Corona. Per tanggal 3 januari dilaporkan sebanyak 44 kasus kematian akibat COVID-19. Pada bulan Maret 2020, COVID-19 hadir di Indonesia. Presiden Republik Indonesia mengkonfirmasi adanya masyarakat yang terpapar virus Corona. Sejumlah 1,528 kasus dan 136 kasus kematian. (Adityo, dkk, 2020) hingga tanggal 5 agustus 2021, total terkonfirmasi terpapar 3.568.331 kasus dan sebanyak 102.375 orang meninggal dunia. Hal ini membuktikan tingkat penyebaran COVID-19 masif terjadi. Penyebaran kasus COVID-19 juga memungkinkan terjadi kepada OTG atau Orang Tanpa Gejala (Wiraharja, 2020).

Dalam waktu kurang lebih 20 bulan persebaran COVID-19 masih belum juga mengalami titik temu untuk berakhir dan masih berpotensi untuk menyebar secara luas. Wabah ini mengancam keselamatan manusia. Data Saat ini yang dipublikasi di web www.covid19.go.id, total data dari 223 negara yang terkonfirmasi covid per tanggal 18 Agustus 2021 adalah sebanyak 209.470375 orang dan 4.377.979 orang meninggal dunia. Di Indonesia korban COVID19 mencapai 3.908.247 orang, sembuh 3.443.903, dan meninggal dunia 121.141. Roda 
perputaran ekonomi sebagian besar negara mengalami kemerosotan, termasuk di Indonesia. Kepala Dana Moneter Internasional (International Monetary Fund), Kristalina Georgieva di BBC News Tanggal 9 april 2020 mengatakan krisis ekonomi depression yang terjadi di tahun 1930. Kejadian tersebut menjadikan krisis terpanjang melibatkan banyak negara di abad 20 (Sjafiatul, dkk, 2020). Di Indonesia, krisis ekonomi membuat sebagian besar lapangan pekerjaan mulai langka dan cenderung memberhentikan karyawan untuk menutupi turunnya penghasilan. Badan Pusat Statistik membuat laporan terkait orang yang kehilangan pekerjaanya sebanyak 3,5 juta akibat pandemi virus Corona dan total keseluruhan pengangguran yang ada di Indonesia mencapai 29,12 juta orang (IDX Channel.com, 21 Januari 2021).

Penanganan Corona masih belum terselesaikan tuntas di Indonesia hingga pertengahan tahun 2021. Pandemi menjadi darurat kesehatan yang bersifat langsung. Salah satu kebijakan social distancing menekan persebaran virus ternyata juga berdampak pada ekonomi di berbagai lapisan masyarakat (S. Wahyudi \& Kusuma, 2020). Terbukti dengan adanya peraturan tersebut, masyarakat banyak terkena imbasnya dari mulai sektor perdagangan, pendidikan, transportasi darat dan laut, dan ekonomi itu sendiri. Adanya aturan baru bernama Pembatasan Sosial Berskala Besar (PSBB) kemudian diganti dengan Pemberlakuan Pembatasan Kegiatan Masyarakat (PPKM) Mikro, hingga kondisi Indonesia di bulan Juni dan juli mengalami lonjakan signifikan, muncul PPKM Darurat dan dilanjutkan dengan PPKM Level 4 tertuang dalam aturan instruksi menteri Nomor 34 Tahun 2021 tentang Pemberlakuan Pembatasan Kegiatan Masyarakat Level 4, Level 3 dan Level 2 Coronavirus Disease 2019 di Wilayah Jawa dan Bali. Kejadian ini membuat daya beli masyarakat tertekan dan kondisi Ekonomi sampai ujung 2021 diprediksi melemah (ekonomi.bisnis.com, 18 Agustus 2021). Bank Indonesia mencatat, Indeks Ekspektasi Kondisi Ekonomi pada Juli 2021 zona pesimis sebesar 93,2 persen. IEK di bulan Juni 2021 masih ada di zona sebesar 123,4 persen. Data dari Badan Pusat Statistik memaparkan data. Tingkat Pengangguran Terbuka (TPT) bulan Februari 2021 sebesar 6,26 persen. Sedangkan 19,10 juta orang atau 9,30 persen penduduk dalam usia kerja yang terdampak pandemi. Diantaranya pengangguran karena COVID-19 sebanyak 1,62 juta orang, bukan angkatan kerja karena COVID-19 sebanyak 0,65 juta orang, sedangkan tidak bekerja karena COVID-19 sebesar 1,11 juta orang, dan penduduk yang mengalami pengurangan jam kerja karena COVID-19 sebesar 15,72 juta orang.

Data di atas menunjukkan tingkat ekonomi masyarakat semakin menurun akibat pandemi COVID-19. Kebutuhan masyarakat semakin meningkat sedangkan pendapatan menurun dan beberapa masyarakat mengalami pemberhentian kerja di tempat kerja dari berbagai sektor lapangan pekerjaan. Sehingga muncul adanya kesenjangan ekonomi yang terlihat dari kebutuhan tidak sebanding lurus dengan pendapatan. Bukan hanya masalah pandemi COVID-19 semakin meningkat tetapi tingkat kematian akibat covid, beban menghidupi keluarga, dan kondisi masyarakat masih tidak stabil. Masalah kemiskinan juga menjadi perhatian khusus pada saat pandemi COVID-19. Tercatat yang diekspos oleh BBC News mengungkapkan bahwa kemiskinan di Indonesia berjumlah 2,7 juta dan pemulihan ekonomi memakan waktu yang lama (Wijaya, 2021). Kemiskinan adalah keadaan dimana terjadi ketidakmampuan untuk memenuhi kebutuhan dasar seperti sandang, pangan, papan, kesehatan dan pendidikan. Kemiskinan dapat disebabkan oleh langkanya bahan pemenuh kebutuhan dasar ataupun kurangnya pendidikan dan pekerjaan. Kebanyakan negara berkembang dilanda permasalahan kemiskinan ini (Armylasari, 2017).

Sejak Maret 2020, Pemerintah telah memberikan bantuan sosial berupa Bantuan Langsung Tunai (BLT) sebesar 600.000/KK/Bulan yang disalurkan untuk 3 bulan, diantaranya Maret, April dan Mei 2020 dan berjalan hingga Agustus 2021. Dana bantuan pemerintah tersebut berasal dari APBN, APBD Provinsi, APBD Kabupaten dan Dana Desa. Realitas yang terjadi, bantuan dari pemerintah saja bukan menjadi solusi yang memadai untuk kesejahteraan ekonomi masyarakat yang terpapar COVID-19. Bantuan tersebut tidak cukup untuk keluarga yang memiliki tanggungan anggota keluarga yang banyak atau kehilangan usaha dan pekerjaannya. Oleh karena itu, penanganan akibat dan dampak dari penyebaran COVID-19 ini tidak hanya mengandalkan civitas pemerintahan saja, melainkan perlu adanya kegiatan dari masyarakat dengan bentuk pemberdayaan untuk menyalurkan bantuan-bantuan secara 
independen dengan membentuk sebuah komunitas peduli. Partisipasi nyata dari masyarakat yang tergolong mampu secara finansial bisa direalisasikan dengan bentuk tenaga, uang dan harta benda. Selain itu, partisipasi buah pikiran, pengambilan keputusan dan representative juga bisa dijadikan sebagai bentuk partisipasi sosial yang tidak nyata untuk bisa dilakukan (Sastropoetro, 1988).

Keberhasilan suatu kebijakan pemerintah tidak hanya ditentukan oleh peranan pemerintah saja, melainkan peran dan partisipasi masyarakatnya (Islamiyah, 2018). Partisipasi masyarakat bisa diwujudkan dalam sebuah komunitas didalamnya terdapat penggerak anak muda, yang bukan hanya bergerak untuk mengedukasi, sosialisasi saja. Perlu adanya sebuah tindakan nyata untuk menanggulangi dampak sosial ekonomi dan keluarga miskin akibat COVID-19. Organisasi dan komunitas juga turut andil saling bantu masyarakat untuk tetap bertahan di kondisi serba kekurangan, baik dalam ekonomi, pendidikan, dan kebutuhan seharihari. Hadirnya komunitas Kecil Bergerak Indonesia (KBI) menjadi sebuah bukti nyata sikap partisipatif untuk membantu masyarakat yang terpapar COVID-19 di wilayah Sidoarjo, Jawa Timur. Melalui kegiatan pengumpulan donasi, baik berupa sembako, uang, bantuan pendidikan dan makanan hingga proses pendistribusian donasi untuk dialokasikan kepada masyarakat wilayah Sidoarjo. Kegiatan yang dilakukan oleh komunitas Kecil Bergerak Indonesia tidak terlepas dari adanya masalah ekonomi masyarakat di masa pandemi ditambah pada masa PPKM.

Penulisan sejenis telah dilakukan dengan judul "Peran Pemerintah Desa Dalam penyaluran Bantuan Langsung Tunai Pada Masyarakat di Masa Pandemi COVID-19 di Kecamatan Maesaan Kabupaten Minahasa Selatan" (Wowiling, 2021) dengan fokus bantuan masyarakat berupa uang tunai kepada masyarakat Minahasa Selatan. Penelitian ini menggunakan metode kualitatif mengkaji tentang bantuan pemerintah desa menyalurkan bantuan langsung tunai (BLT) masa pandemi COVID-19 di masyarakat Minahasa. Hasil penelitian menunjukkan bahwa tingkat penyaluran BLT tidak merata kepada masyarakat yang benar-benar membutuhkan tetapi justru ada masyarakat mampu mendapatkan bantuan pemerintah yang disalurkan pemerintah desa.

Bantuan COVID-19 seharusnya diberikan berbarengan pada saat berjalannya kebijakan lockdown atau pembatasan kegiatan masyarakat, baik dari sektor pekerjaan sampai dengan perdagangan. Dengan adanya bantuan covid diharapkan bisa menghambat laju kemerosotan ekonomi yang semakin menurun, bantuan ini bersifat sementara untuk menghambat bukan menaikkan taraf ekonomi masyarakat. Menjalankan pertumbuhan ekonomi yang dirangsang konsumsi masyarakat tidak boleh diabaikan. Dan dalam perekonomian yang masih didominasi sektor ekonomi rakyat, kestabilan dan bahkan kenaikan konsumsi masyarakat (secara relatif maupun absolut) harus dianggap sebagai faktor penyelamat pertumbuhan ekonomi nasional (Mubyarto, 2001).

Pemberian bantuan terhadap masyarakat miskin merupakan suatu hal yang memang perlu dilakukan pemerintah untuk pengentasan masalah kemiskinan agar kesejahteraan masyarakat meningkat. Namun kenyataan yang terjadi di masyarakat, bantuan langsung tunai bukan menjadi jawaban permasalahan kemiskinan di Indonesia. Adanya dampak yang ditimbulkan tidak hanya dari sisi positifnya saja, melainkan banyak juga membawa dampak yang negatif. Oleh sebab itu, peningkatan kesejahteraan masyarakat melalui bantuan langsung dari pemerintah itu dianggap belum maksimal dalam membantu perekonomian masyarakat (Selviana, Akib \& Risfaisal, 2016).

Bertolak dari hasil penulisan diatas dengan temuan bahwa belum meratanya bantuan pemerintah kepada masyarakat terdampak maka sudah saatnya masyarakat sebagai komponen penting dalam pembangunan harus turut serta berkontribusi apa pun itu bentuknya. Penelitian ini bertujuan untuk melihat peran salah satu komunitas anak muda yang bergerak dalam bidang kemanusiaan untuk meningkatkan dan membantu masalah ekonomi masyarakat khsusunya di wilayah Sidoarjo Jawa Timur, yang memberikan bantuan kepada masyarakat yang mengalami kondisi kekurangan akibat pandemi COVID-19. Praktik seperti ini sebagai bentuk kesadaran anak muda akan pentingnya saling membantu dalam hal kebutuhan sehari-hari (Tanim, 2011). Melihat realitas yang ada dan begitu semangatya Komuntas Kecil Bergerak Indonedsia dalam 
berkontribusi membantu masyarakat maka sangat urgen penelitian ini dilakukan sebagai inspirasi bagi masyarakat lain atau komunitas lain untuk saling membantu apalagi di masa pandemi, tidak hanya bantuan fisiknya saja tapi rasa empati kepada sesama juga sangat penting

Menurut Kertajaya Hermawan (2008) komunitas adalah sekelompok orang saling peduli satu dengan lain lebih dari yang seharusnya, di mana dalam sebuah komunitas terjadi relasi pribadi yang erat antara para anggota komunitas tersebut karena adanya kesamaan interest atau values. Komunitas sosial adalah perkumpulan atau kesatuan manusia yang hidup bersama, karena adanya hubungan diantara mereka. Hubungan tersebut antara lain menyangkut hubungan timbal balik yang saling mempengaruhi dan juga suatu kesadaran untuk saling menolong (Soekanto, 2006). Tujuan saling tolong menolong ini membuat pergerakan untuk membantu orang lain secara sukarela dengan dorongan hati masing-masing. Pergerakan yang tercipta akan menumbuhkan humanism dalam diri, meningkatkan kepekaan untuk berbagi dan menjadikan menebar kebaikan sebagai salah satu bentuk pergerakan dari sekumpulan manusia dalam satu visi misi.

Tujuan kegiatan KBI dilakukan untuk membantu pedagang, pekerja yang di PHK, dan masyarakat terdampak COVID-19 dari sisi kamanusiaan supaya kehidupan yang dijalani semakin membaik. Masayarakat yang tidak terjamah bantuan pemerintah, KBI terjun secara langsung untuk melihat kondisi penerima manfaat dan membuktikan secara langsung supaya pemberian bantuan yang diberikan akan secara tepat.

\section{METODE}

Penulisan ini menggunakan jenis penelitian kualitatif bertujuan untuk memaparkan dan memberikan gambaran tentang subyek yang diteliti. Adapun fokus penelitian ini adalah komunitas Kecil Bergerak yang aktif dalam kegiatan penyaluran bantuan sosial kepada masyarakat yang terdampak COVID-19 di wilayah Sidoarjo Jawa Timur. Sumber data dalam penelitian ini terbagi menjadi dua yaitu data primer dan sekunder, dalam proses penelitian membutuhkan informan kunci dengan menggunakan teknik purposive sampling, dalam penelitian ini yang menjadi informan kunci adalah Account Executive komunitas Kecil Bergerak Indonesia, Ajeng Adinda Putri.

Teknik pengumpulan data dengan cara obeservasi, yaitu pengamatan langsung di lapangan, bagaimana komunitas Kecil Bergerak Indonesia beraktifitas baik di dalam realitas sosial masyarakat maupun observasi di media sosial yang dimiliki komunitas KBI. Teknik berikutnya dengan wawancara untuk mendapatkan data utama dari informan baik pimpinan KBI maupun anggota lainnya serta studi dokumentasi untuk melengkapi data-data yang diperoleh dari wawancara dengan informan. Analisis data yang digunakan dengan reduksi data, penyajian data, dan penarikan kesimpulan. Aktivitas dalam analisis data kualitatif dilakukan secara interaktif dan berlangsung secara terus-menerus sampai tuntas.

\section{HASIL DAN PEMBAHASAN}

\subsection{Peran Komunitas Kecil Bergerak Indonesia (KBI)}

Berawal dari pengamatan di sosial media Instagram, penulis melihat adanya sebuah akun komunitas yang bergerak di lingkup sosial dengan berbagai program bantuan yang disalurkan kepada masyarakat tertentu, terutama masyarakat terdampak pandemi COVID-19. Komunitas tersebut bernama Kecil Bergerak Indonesia. Berdasarkan hasil wawancara yang peneliti lakukan bersama Account Executive komunitas, Ajeng Adinda Putri, menjelaskan bahwa komunitas Kecil Bergerak Indonesia dibentuk sejak tahun 2019 dan sudah memiliki legalitas pada tahun 2021 dan memiliki beberapa anggota termasuk Hubungan masyarakat (Humas) untuk memperluas jaringan. Kecil Bergerak Indonesia didirikan oleh pegiat lintas akademis di Sidoarjo. Komunitas tersebut fokus pada isu sosial, lingkungan dan kesehatan yang bersifat kolektif. Kecil Bergerak Indonesia fokus melaksanakan aksi sosial berskala kecil dan 
berkelanjutan untuk masyarakat di wilayah Sidoarjo dan sekitarnya. Satu hal yang mendorong terbentuknya komunitas ini adalah mengenai kepedulian terhadap kondisi ekonomi masyarakat selama pandemi COVID-19.

Adapun program bantuan yang telah dilaksanakan oleh komunitas Kecil Bergerak Indonesia antara lain, paket sembako yang disalurkan kepada para pekerja informal, korban PHK dan ibu hamil. Rincian sebagian sembako yang disalurkan kepada masyarakat, meliputi paket kardus berisi bahan pokok, pampers, susu, serta kebutuhan primer lainnya. Terdapat pula bantuan uang tunai kepada orang sakit, kaum dhuafa, yatim piatu dan difabel. Pendistribusian bantuan medis, pendampingan kesehatan, hadiah natal, 1001 kado lebaran hingga beasiswa jenjang TK-perguruan tinggi juga dilakukan dan berhasil direalisasikan. Beberapa rencana kegiatan yang dijalankan oleh Kecil Bergerak Indonesia tertulis dalam proposal, sehingga menjadi fokus, terstruktur dan tepat.

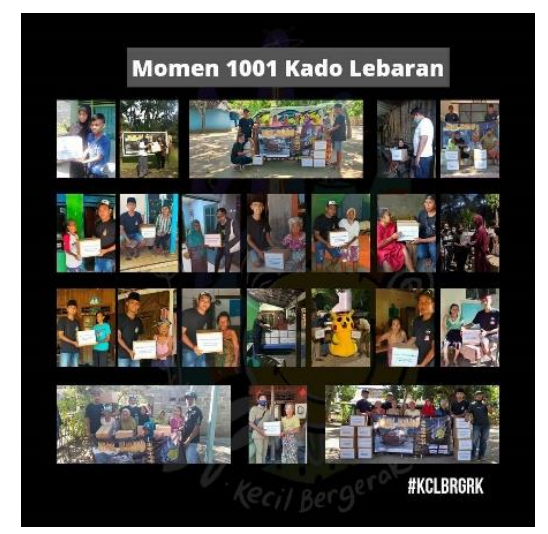

Gambar 1. 1001 kado lebaran dibagikan di Sidoarjo - Situbondo

\subsection{Sumber Dana Bantuan}

Kecil Bergerak Indonesia (KBI) memperoleh sumber dana bantuan yang terbagi atas dua kategori, yaitu dana organik dan non organik. Dana organik berasal dari dana pribadi setiap anggota yang dikumpulkan serta open donasi kepada para donatur yang bersedia ikut bergerak dalam keberhasilan komunitas ini. Adapun dana non organik adalah dengan langkah promosi atau menyebarkan informasi melalui kitabisa.com dan beberapa platform media sosial yang lainnya. Media partner tentunya sangat dibutuhkan, sebab komunitas tidak dapat berdiri tanpa anggota secara intern, dan komunitas tidak mampu berkembang tanpa adanya kerjasama dengan komunitas ekstern. Kerja sama pada intinya menampilkan terdapatnya konvensi antara dua orang tau lebih yang silih menguntungkan. Kerja sama ialah aktvitas bersama dua orang ataupun lebih yang dicoba secara terpadu yang ditunjukan kepada sesuatu sasaran atau tujuan tertentu (Nugroho \& Suprapto, 2021).

Dana program yang sudah berjalan beberapa dari donatur yang sukarela menyisihkan penghasilannya guna membantu sesama. Ditambah dengan bentuk kerjasama dari berbagai pihak dan influencer Rachel Venya, di antara pihak yang berkolaborasi DKM Surabaya, Alumni SMANDA, Dompet Kepedulian Muslim, PT. Diki Jaya, Dolor Darjo, DQ (Giving is amazing), Yatim Mandiri, Seribu Senyum, Warga Desa Lebo, Warga Desa Keboharan, Santara, Para Pahlawan kebaikan, EHHMH Snack, Saos Tiga Anak, Street Children Foundation dan REAKSI (Relawan Kebencanaan dan Sosial). Semua melakukan kolaborasi dengan Kecil Bergerak Indonesia tujuan yang sama untuk saling berbagi dengan niatan baik memberikan apa yang dimiliki untuk dikasih.

\subsection{Proses Pendistribusian Bantuan}

Pada tahap pendistribusian bantuan, Kecil Bergerak Indonesia (KBI) melakukan tahapan mini riset terlebih dahulu. Para anggota melakukan observasi ke beberapa individu tertentu untuk dijadikan sebagai sasaran penerima bantuan ini. Mini riset dilakukan dengan bantuan 
beberapa pihak terkait, seperti data dari pemerintah desa setempat terkait pemetaan kondisi ekonomi warganya. Pendistribusian bantuan yang dilakukan oleh tim komunitas Kecil Bergerak Indonesia terbatas untuk wilayah Sidoarjo dan sekitarnya, seperti Malang, Surabaya, Situbondo, Jombang dan Lumajang. Berdasarkan lanjutan wawancara bersama founder Kecil Bergerak Indonesia, total penerima bantuan untuk bulan Januari-April 2021 terbagi atas beberapa kategori. Paket sembako yang diterima oleh dhuafa sebanyak 3.987, 173 beasiswa pendidikan untuk anak, sebanyak 12.050 nasi bungkus untuk program razia perut lapar, dan 17,5 ton untuk himpunan beras. Selain itu, terdapat pula bantuan uang tunai sebesar Rp77.800.000 untuk anak Yatim dan Piatu, serta Rp53.200.000 untuk disalurkan kepada kaum duafa.

Peneliti melihat Instagram Kecil Bergerak Indonesia tidak hanya mendistribusikan bantuan berupa makanan dan sembako saja, tetapi juga berbentuk bantuan uang tunai untuk memenuhi kehidupan keluarga dan anak. Perlu pendataan warga di setiap wilayah yang memang benar-benar membutuhkan (Selviana, 2016). Di antara saluran persebaran bantuan uang bagi warga terdampak covid yakni Pak Sastro menjalani kehidupan menjadi tukang ojek online dan penghasilannya berkurang drastis akibat pandemi Covid, sedangkan kedua anaknya yang harus melanjutkan ke jenjang Sekolah Dasar dan Sekolah Menengah Kejuruan. Ada Pak Jurianto yang bekerja serabutan di tengah pandemi COVID-19 demi memenuhi kebutuhan keluarga dan terapi anaknya yang didiagnosa mengidap gangguan saraf motorik. Biaya bantuan yang diserahkan kepada warga membutuhkan dari berbagai donatur insidentil dan kerjasama dengan berbagai pihak untuk menyukseskan program bantuan yang akan disalurkan ke depannya.

Menurut Rondinelli dalam artikel Kadji (2017) mengemukakan ada 3 cara strategi untuk menyalurkan atau membantu penduduk yang membutuhkan, Pertama, dorongan disalurkan ke tempat dimana kebanyakan orang miskin hidup, lewat program pembangunan desa terpadu ataupun proyek penciptaan pelayanan yang berorientasi pada penduduk desa. Jangkauan program akan tepat sasaran kepada orang yang benar-benar membutuhkan. Kedua, dorongan dipusatkan buat menanggulangi cacat standar kehidupan orang- orang miskin lewat program kebutuhan dasar manusia. Batuan yang disalurkan sudah dalam tahap pertimbangan sesuai kebutuhan orang miskin, sehingga akan terbantu menyesuaikan kebutuhan mereka. Ketiga, dorongan dipusatkan pada kelompok yang memiliki karakteristik sosio ekonomi yang sama yang mendesak ataupun mempertahankan mereka buat terus berkubang di dalam bundaran kemiskinan lewat proyek yang dirancang untuk warga tertentu. Serta ditinjau dari segi penghasilan, lingkungan sekitar dan keluarga agar semua merata yang akan diberi bantuan.

Bantuan yang disebabkan PPKM Darurat sepanjang bulan Juli 2021 membuat ekonomi semakin turun, Kecil Bergerak Indonesia hadir dengan membuat program berbagi PPKM (Posko Pangan Kembali Mengudara) bahan pangan, kemudian didistribusikan wilayah Sidoarjo berupa beras, minyak, mie instan, teh celup, dan sebagainya. Bantuan ini diberikan kepada warga yang Isoman (Isolasi Mandiri) yang sedang membutuhkan bantuan. Program ini memiliki jargon 'Bantu Rakyat Kuat'.

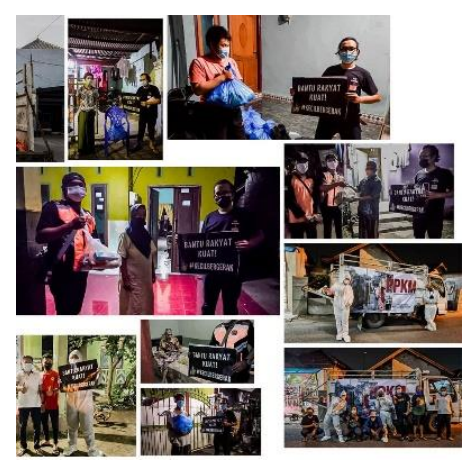

Gambar 2. Pembagian Posko Pangan Kembali Mengudara

Adapun program yang serupa bekerja sama dengan influencer Rachel venya yang melaksanakan razia borong semua dagangan pedagang kaki lima, beroperasi di era PPKM. Hasil 
dari borongan tersebut disalurkan kepada orang yang menjalani Isolasi Mandiri dan ditambah dengan bantuan sembako. Tidak hanya itu saja, momen hari raya qurban juga dimanfaatkan Kecil Bergerak Indonesia (KBI) sebagai aksi berbagi daging kurban. Pendistribusian daging kurban ini kepada ojek online, masyarakat miskin, Pedagang Kaki Lima, dan orang yang meminta-minta.

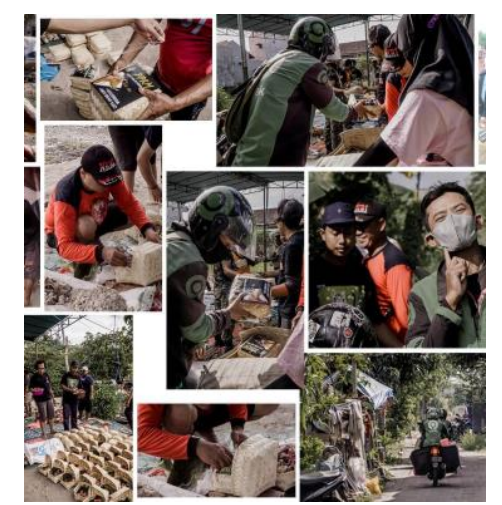

Gambar 3. Pembagian Posko Pangan Kurban Massal

\subsection{Dampak Bantuan Kecil Bergerak Indonesia}

Setiap program akan mengalami sebagian tantangan Pertama, pencairan dana kepada penerima khasiat yang pas. Mencari data terkait masyarakat yang terkena dampak pandemi COVID-19, orang miskin, dan warga yang membutuhkan uang untuk membayar keperluan ekonomi dan pendidikan. Kedua, penyaluran nilai serta jumlah dorongan yang pas. Setelah melihat dari kebutuhan masyarakat yang akan di bantu, sehingga bisa memutuskan berapa besar jumlah sesuai kebutuhan. Ketiga, durasi program. Melihat persebaran bantuan perlu dilihat durasi program yang akan dijalankan, apakah sekali atau secara terus menerus. Karena dilihat dari kebutuhan bisa menjadi acuan untuk membuat program yang sekali jalan atau butuh kelanjutan (Pramanik, 2020).

Dampak persebaran batuan komunitas Kecil Bergerak Indonesia dirasakan ibu rumah tangga yang dibantu dibelikan susu formula untuk bayi, dan bantuan sekolah anak untuk melanjutkan ke jenjang yang lebih tinggi. Periode bantuan yang diberikan bersifat relatif, tergantung keperluan dan kebutuhan penerima manfaat. Uang dengan sejumlah besar akan diberikan secara bertahap, supaya tidak menggantungkan dan malah menyepelekan hingga akhirnya tidak bekerja, karena sudah mendapatkan bantuan yang sangat banyak. Parade pembagian makan secara estfet membagikan kepada orang-orang yang kelaparan diwilayah pinggir jalan Sidoarjo sampai Surabaya, program tersebut dinamakan Razia Perut Lapar hingga sekarang berubah menjadi Posko Pangan Kembali Mengudara jilid lima.

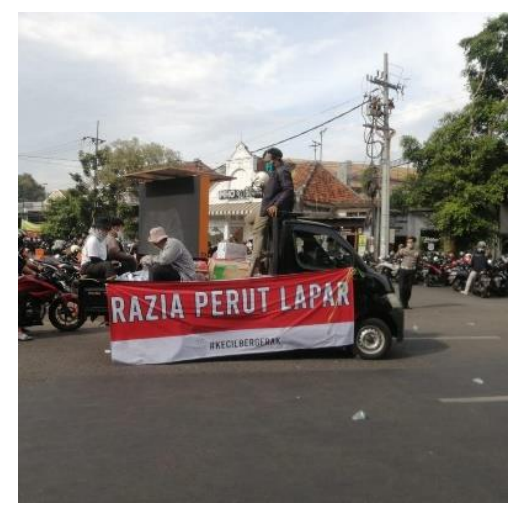

Gambar 4. Pembagian makanan dengan program Razia Perut Lapar

Hal yang sama juga dirasakan oleh pedagang-pedagang kaki lima yang diborong habis dagangan mereka, dan dagangan mereka diberikan lagi kepada orang yang menjalani isolasi 
mandiri. Penambahan bantuan berupa sembako berisikan bahan pangan, hal ini dapat membuat orang akan bersemangat untuk menjalani rutinitas menuju kesembuhan. Butuh kerjasama dan tenaga untuk mensukseskan kegiatan ini.

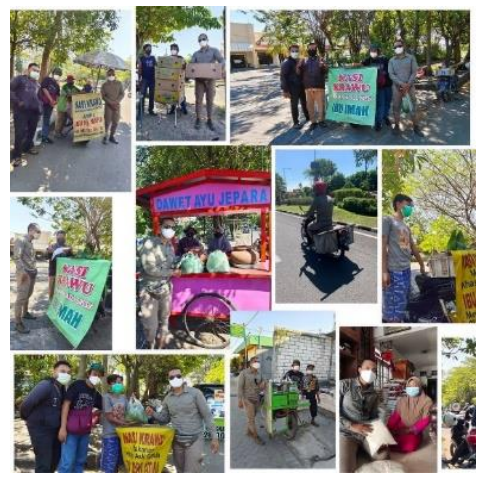

Gambar 5. Memborong dagangan pedagang kaki lima

Program sebelumnya yakni, Aqiqah gratis yang ke-1 untuk keluarga pra sejahtera. Bantuan aqiqah gratis disalurkan di rumah mbah Sai'in selaku tuan rumah dan penerima manfaat program, bertempat di Desa Keboharan, Kecamatan Krian, Kabupaten Sidoarjo. Di tempat yang sama juga mengadakan bedah rumah secara gratis, di rumah mbah Kusni yang program ini bertujuan untuk hidup layak dan nyaman di segala keterbatasan yang dimiliki penerima manfaat.

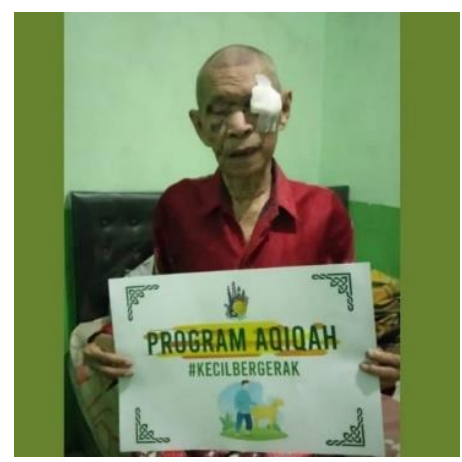

Gambar 6. Program aqiqah untuk mbah sai'in

Pengiriman bantuan tidak hanya kepada masyarakat yang terkena dampak pandemi COVID-19, melainkan juga membantu masyarakat yang mengalami musibah bencana alam berupa banjir, program ini disebut tanggap darurat. Tanggal 7 februari 2021 mengirim bantuan di kabupaten Jombang yang mengalami banjir karena jebolnya taggul sungai brantas yang menerjang 4 Desa. Bantuan diberikan berupa bahan pangan, dan tenda temat untuk pengungsian sementara.

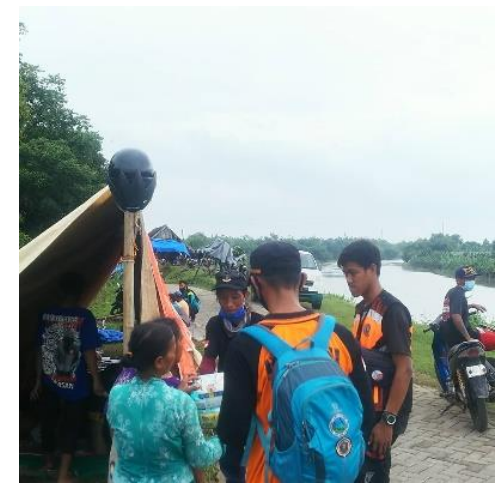

Gambar 7. Pendistribusian bantuan banjir Jombang 
Bantuan-bantuan diberikan berupa bahan pangan, uang dan tenaga oleh Komunitas Kecil Bergerak Indonesia yang berkolaborasi dengan berbagai pihak dan individu, dapat menuai dampak yang positif kepada masyarakat yang menerima manfaat. Apalagi Kecil Bergerak Indonesia yang notabene anak muda, dari paparan wawancara Ajeng, anak muda tidak hanya wacana, wacana dan wacana saja tetapi butuh aksi nyata dan berkelanjutan. Kegiatan yang dilakukan ini dengna yakin meskipun kecil untuk kebaikan yang berdampak.

\subsection{Faktor Pembentukan Kecil Bergerak Indonesia}

Berdirinya Komunitas Kecil Bergerak Indonesia dipengaruhi oleh dua faktor, yaitu faktor pendorong dan penghambat. Adanya program bantuan sosial dari pemerintah tidak bisa mengakomodir kebutuhan masyarakat secara menyeluruh menjadi bagian dari faktor pendorong berdirinya komunitas Kecil Bergerak Indonesia. Pada umumnya, faktor pendorong bersifat sosial-psikologis, yang menimbulkan motivasi individu secara spesifik (Pitana \& Gayatri, 2005). Tugas penyaluran bantuan ini tidak hanya diberikan kepada pemerintah semata, melainkan semua kalangan masyarakat, organisasi dan komunitas untuk turut membantu bergerak dalam hal kemanusiaan di masa pandemi COVID-19.

Program bantuan sosial dari pemerintah yang memiliki beberapa tantangan, seperti pencairan dana yang tidak tepat sasaran, durasi program, dan penyaluran jumlah nilai yang dinilai kurang tepat (Pramanik, 2020). Oleh sebab itu, pentingnya kesadaran dari setiap golongan, termasuk komunitas untuk membantu menyalurkan bantuan sosial secara independen. Penyaluran bantuan sosial yang diberikan oleh Kecil Bergerak Indonesia terbilang cukup kompleks, mulai dari uang tunai, paket sembako, kebutuhan medis dan kesehatan hingga program bantuan untuk pendidikan berupa beasiswa. Hal tersebut tentu memiliki nilai penting untuk kelangsungan hidup masyarakat, terutama bagi masyarakat yang benar-benar membutuhkan bantuan di kala terdampak pandemi.

Penetapan tujuan pembentukan komunitas Kecil Bergerak Indonesia tentu perlu diimbangi dengan hubungan internal dari setiap anggota. Komunitas ini memiliki anggota dengan struktural yang baik, sehingga dapat bermanfaat untuk pengembangan relasi dan bisa mengembangkan sasaran lebih jauh dan menyeluruh. Founder komunitas Kecil Bergerak adalah seorang akademisi yang bergerak dalam isu kemanusiaan sehingga dapat mendukung kinerja komunitas secara maksimal dan semakin baik kedepannya. Struktur pengurus Komunitas Kecil Bergerak Indonesia, yakni Ardi sebagai Ketua, Sekretaris, bendahara, Glen selaku humas, media, Transport, dan Ajeng sebagai account executive. Pentingnya unsur struktur dalam sebuah organisasi atar kominitas sebagai gambaran umum tentang cara membangun koordinesi antar angora satu dengan selainnya. Sejalan dengan pendapat Griffin \& Moorhead dalam buku manajemen SDM, mengatakan bahwa struktur organisasi merupakan sistem tugas, pelaporan dan hubungan interaksi baik secara horizontal maupun vertikal (Kusumaryoko, 2021). Dengan adanya struktur tersebut menjadikan legalitas akan semakin dipercaya secara luas.

Ditambah setiap anggota memiliki visi misi yang sama untuk bergerak dan terdorong untuk membantu sesama manusia tanpa melihat latar belakang mereka. Hal ini bisa menjadi faktor dukungan untuk bergerak lebih cepat tanpa ada paksaaan dari orang lain, secara sadar membantu dan terjun langsung ke lapangan untuk mewujudkan tujuan tersebut. Satu kesatuan tersebut menjadi bagian dari bentuk harmonisasi, yang dapat diartikan sebagai bentuk kerja sama sehingga menciptakan keselarasan dan keutuhan dalam hidup bermasyarakat (Sharastuti, Yanzi \& Nurmalisa, 2018).

Adapun faktor yang dinilai sebagai faktor penghambat bergeraknya Kecil Bergerak Indonesia ini juga terbagi menjadi dalam lingkup internal dan eksternal. Anggota tim komunitas yang menjadi faktor pendorong sekaligus menjadi faktor penghambat dalam lingkup internal. Profesionalisme teamwork yang sudah dibentuk bisa saja menghilang akibat ego setiap individu (Indrawati, 2017). Adanya anggota yang kurang bertanggung jawab untuk menindaklanjuti perihal evaluasi juga pasti terjadi dalam pembentukan sebuah komunitas. Selain itu adanya keterbatasan ruang dan waktu serta sarana dan prasarana juga termasuk ke dalam 
kemungkinan kendala yang dapat menghambat aktivitas komunitas ini. Selain dalam lingkup internal, faktor penghambat yang dilihat dari ruang lingkup eksternal bisa berasal dari jumlah para donatur umum. Keterlambatan komunikasi dengan donatur juga akan mempengaruhi proses pelaksanaan tujuan atau kegiatan utama Kecil Bergerak Indonesia. Kondis SDM yang terbatas, sehingga butuh bantuan tenaga ekstra dari kawan-kawan penggerak lainnya untuk turut andil dalam aksi kemanusiaan.

Segala aktivitas dilakukan secara mandiri, baik dalam menjalankan program sampai pencarian dana. Kondisi tersebut bisa menjadi hambatan dalam pelaksanaan program yang memiliki target bantuan yang luas. Apalagi jangkauan terkait persebaran tidak hanya disebarkan di wilayah Sidoarjo saja, melainkan sekitarnya juga. Penyebarluasan cabang dan relasi untuk setiap anggota diperlukan untuk ke depannya.

Hasil kegiatan ini menunjukkan peran serta komunitas Kecil Bergerak Indonesia untuk mendistribusikan bantuan sosial kepada masyarakat yang terdampak pandemi COVID-19 di wilayah Sidoarjo dan sekitarnya. Setiap pembentukan komunitas pasti memiliki pendorong dan penghambat, baik dari internal maupun eksternal. Kerjasama dan tanggung jawab setiap anggota komunitas akan sangat menentukan kemajuan suatu komunitas tersebut. Komunitas Kecil Bergerak Indonesia akan terus bertahan untuk menunjukkan dedikasi dan peran nyata dalam membantu masyarakat Indonesia apabila mampu menghalau hambatan yang ada.

Seluruh kegiatan yang dilakukan oleh Komunitas Kecil Bergerak Indonesia di Sidoarjo, mulai dari pembagian makanan, uang, memborong pedagang, dan sebagainya dilaksanakan dengan mengedepankan sisi kemanusiaan, kebutuhan mereka tinggi tetapi tidak sebanding dengan apa yang mereka miliki. Pembagian sembako dan bantuan selainnya KBI tidak memandang dari agama, suku dan latar belakang. Walaupun kegiatan ini dilakukan secara mandiri, tidak hanya sekedar membagian kepada orang yang membutuhkan melalui data terjun secara langsung. Sehingga KBI Sidoarjo memberikan bantuan kemanusiaan secara cepat dan tepat tanpa adanya kecemburuan sosial di wilayah bantuan.

\section{KESIMPULAN}

\subsection{Kesimpulan}

Kebijakan pemerintah yang sudah secara massif memberikan bantuan kepada masyarakat terdampak COVID-19, dirasa perlu ada partisipasi dari banyak komponen mengingat luasnya wilayah dan banyaknya penduduk Indonesia. Komunitas Kecil Bergerak ndonesia adalah salah satu komponen masyarakat yang mulai tergerak dari kesadaran dari setiap anggotanya untuk ikut berperan serta dalam memaksimalkan stabilisasi perekonomian negara. Kecil Bergerak Indonesia (KBI) merupakan komunitas yang memiliki peran untuk berpartisipasi dan mengeksplorasikan tindakan nyata dalam menyalurkan bantuan sosial kepada masyarakat terdampak pandemi COVID-19 di wilayah Sidoarjo dan sekitarnya. Kecil Bergerak Indonesia (KBI) menyalurkan bantuan sosial berupa sembako bahan pokok, uang tunai, santunan kepada yatim piatu, orang miskin dan kaum dhuafa, pemberian hadiah natal dan lebaran, serta beasiswa pendidikan untuk TK sampai perguruan tinggi. Beberapa sumber dana yang diberikan berasal dari dana pribadi setiap anggota komunitas, donatur, kerjasama dengan instansi dan juga open donasi kepada masyarakat umum yang bersedia. Kecil Bergerak Indonesia membuat langkah promosi melalui sosial media Instagram dan mengandalkan kerja sama dengan media sosial eksternal sebagai media partner. Pendistribusian bantuan dilakukan melalui tahapan mini riset ke daerah-daerah yang akan dituju. Faktor satu visi misi setiap anggota tim komunitas Kecil Bergerak Indonesia membuat program ini berjalan tanpa ada paksaan. Lainnya terkait pergumulan yang sama mengenai masalah ekonomi masyarakat semakin menurun akibat pandemi COVID-19. Sehingga muncul pergerakan kemanusiaan yang bisa direalisasikan dengan aksi nyata.

\subsection{Saran}


Penulis menilai adanya Kecil Bergerak Indonesia sangat membantu dalam proses pemulihan ekonomi Indonesia di saat pandemi seperti sekarang ini. Peneliti berharap komunitas ini dapat terus bergerak, walaupun pandemi COVID-19 sudah berakhir serta dapat menginspirasi masyarakat lain untuk lebih peduli kepada sesama sehingga bisa berkontribusi sekecil apapun. Dengan bertambahnya komunitas-komunitas kecil yang peduli diharapkan dapat mengembangkan area jangkauan bantuan sosial kepada masyarakat yang lebih luas dan tidak hanya terbatas untuk masyarakat Sidoarjo dan sekitarnya saja.

\section{DAFTAR PUSTAKA}

Armylasari, Erma Try, (2017). Peran Komunitas Berbagi Nasi Dalam Membantu Pemerintah Untuk Mensejahterakan Kaum Dhuafa. Jurnal Translitera. Edisi. 5

Indrawati, Rizky. (2017). Strategi Pelaksanaan Tim Pemberdayaan Kesejahteraan Keluarga dalam Meningkatkan Pemberdayaan Perempuan di Kecamatan Samarinda Utara. Jurnal Ilmu Pemerintahan, 861-872.

Islamiyah, N. (2018). Tingkat Partisipasi Masyarakat dalam Pembangunan di Desa Sanglepongan Kecamatan Curio Kabupaten Enrekang. Jurusan Ilmu Ekonomi: Universitas Islam Negeri Alauddin Makassar Juliantara.

Kusumaryoko, Prayogo. (2021). Manajeman Sumber Daya Manusia di Era Revolutie Industri 4.0. Yogyakarta: Penerbit Deepublish.

Kertajaya, H. (2008). Arti Komunitas. Jakarta: Gramedia Pustaka Utama.

Mardliyah, Sjafiatul, dkk. (2020) Filantropi Sembako Untuk Masyarakat Terdampak COVID-19. ABDIMAS Bela Negara. Vol. 1 (2)

Mubyarto. (2001). Pemulihan Ekonomi Nasional Menuju Demokrasi Ekonomi. Jurnal Ekonomi dan Bisnis Indonesia. Vol. 16 (1).

Pramanik, N. D. (2020). Dampak Bantuan Paket Sembako dan Bantuan Langsung Tunai Terhadap Kelangsungan Hidup Masyarakat Padalarang Pada Masa Pandemi COVID-19. Intelektiva: Jurnal Ekonomi, Sosial, dan Humaniora, 113-120.

Nugroho, Riant \& Firre An Suprapto. (2021). Kerjasama Pemerintahan antar Desa. Jakarta: Elex Media Komputindo.

Pitana, I Gede \& Gayatri, G Putu. (2005). Sosiologi Pariwisata. Yogyakarta: Andi Offset.

S, M. W., \& Kusuma, H. (2020). Ekonomi Indonesia di Tengah Pandemi Covid 19. Malang: Penerbit Universitas Muhammadiyah Malang.

Sastropoetro. (1988). Partisipasi, Komunikasi, Persuasi dan Disiplin Pembangunan Nasional. Bandung.

Kadji, Yulianto. (2017). Kemiskinan dan Konsep Teorotisnya. https://repository.ung.ac.id/get/simlit res/1/318/Kemiskinan dan Konsep Teroitisnya.p df diakses pada tanggal 27 agusus 2021

Sharastuti, Lintang., Yanzi, Hermi., \& Nurmalisa, Yunisca. (2018). Peranan Paguyuban Masyarakat Bersatu (Pambers) dalam Mewujudkan Harmonisasi Warga Masyarakat. Jurnal Kultur Demokrasi.

Soekanto, S. (2006). Sosiologi Suatu Pengantar. Jakarta: PT. Raja Grafindo Persada.

Susilo Adityo, dkk, (2020). Corona Virus Disease 2019: Tinjauan Literatur Terkini. Jurnal Penyaklit Dalam Indonesia, 7 (1), 45.

Selviana. (2016). Bantuan Langsung Tunai. Jurnal Equilibrium Pendidikan Sosiologi. 126-135

Tamin, Hadi Imron, (2011). Peran Filantropi dalam Pengentasan kemiskinan di Dalam Komunitas Lokal. Jurnal Sosiologi Islam,Vol. 1 (1).

Wiraharja, Regina Satya. (2020). Peranan Ilmu Kesehatan Masyarakat Dalam Penanggulangan COVID-19. Jakarta: Penerbit Universitar Katolik Indonesia Atma Jaya. 
Wowiling, Regina. (2021). Peran Pemerintas Desa Dalam penyaluran Bantuan Langsung Tunai Pada Masyarakat di Masa Pandemi COVID-19 di Kecamatan Maesaan Kabupaten Minahasa Selatan. Jurnal Politico.

Wijaya, Callistasia. (2021, 17 februari). Dampak COVID-19: 2,7 juta orang masuk kategori miskin selama pandemi, pemulihan ekonomi 'butuh waktu lama'. https://www.bbc.com/indonesia/indonesia-55992498 diakses pada tanggal 20 agustus 2021.

Ramalan, Suparjo. (2021, 22 Januari) 3,5 Juta Irang Kehilangan Pekerjaan Akibat Pandemi COVID-19. $\quad$ https://www.idxchannel.com/market-news/35-juta-orang-kehilanganpekerjaan-akibat-pandemi-COVID-19. Diakses pada tanggal 18 agustus 2021

Bayu, Dimas Jarot. (2020, 15 september). Mayoritas Perusahaan Mengalami Penurunan Pendapatan saat

Pandemi.

https://databoks.katadata.co.id/datapublish/2020/09/15/mayoritas-perusahaanmengalami-penurunan-pendapatan-saat-pandemi diakses pada tanggal 21 agustus 2021.

Simamora, Novita Sari. (2021, 10 Agustus) Top 5 News ekonomi: PPKM Diperpanjang, Daya Beli Masyarakat Hingga Susunan Organisasi Kadin. https://ekonomi.bisnis.com/read/20210810/9/1428075/top-5-news-ekonomi-ppkmdiperpanjang-daya-beli-masyarakat-hingga-susunan-organisasi-kadin. Diakses pada tanggal 18 agustus 2021. 